ALVES, MC; MATOSO, ES; PEIL, RMN. 2020. What is the profile of strawberry producers in the south Brazilian region and what do they think about substrate cultivation? Horticultura Brasileira 38: 428-433. DOI: http://dx.doi.org/10.1590/s0102-0536202004014

\title{
What is the profile of strawberry producers in the south Brazilian region and what do they think about substrate cultivation?
}

\author{
Marina C Alves ${ }^{1} \mathbb{D}$; Ester $S$ Matoso ${ }^{1} \mathbb{D}$; Roberta MN Peil ${ }^{1} \mathbb{D}$ \\ Universidade Federal de Pelotas (UFPel), Pelotas-RS, Brasil; mca@ufpel.edu.br; esterschiavon@ufpel.edu.br; ester_schiavon@hotmail. \\ com; rmneil@gmail.com
}

\begin{abstract}
Strawberry production in the south part of Rio Grande do Sul has already been consolidated and, recently, this production has undergone several changes in its cultivation system. The profile of the strawberry producers in this region, and the cultivation systems they use, considering socioeconomic and technological characterization, had not been formally studied since then. This study aimed to characterize the socioeconomic profile of producers, as well as the strawberry production system. Data were obtained through a questionnaire, with questions related to the socioeconomic aspects of the producers and the technical aspects of their cultivation systems. Most of the interviewed producers are male, 26-50 years old, owing up to 20 hectares land, with a monthly income of up to four minimum wages and relying only on family labor. They are considered family producers and have already been growing strawberries in substrate, or are interested in using this modern soilless culture system.
\end{abstract}

Keywords: Fragaria ananassa, socioeconomic status, family farming.

\section{RESUMO}

Qual o perfil dos produtores de morango da região sul do RS e o que pensam sobre o cultivo em substrato?

A produção de morangos no sul do Rio Grande do Sul já está consolidada há alguns anos, sendo que, recentemente a produção passou por várias mudanças no seu sistema de cultivo. O perfil desses produtores bem como o sistema de cultivo utilizado ainda não havia sido objeto de estudo formalizado quanto à caracterização social, econômica e tecnológica. Esse trabalho teve por objetivo caracterizar o perfil socioeconômico dos produtores bem como o sistema produtivo da cultura do morangueiro. Os dados foram obtidos por meio da aplicação de questionário aos produtores, $o$ qual abrangeu questões referentes aos aspectos socioeconômicos dos entrevistados e aspectos técnicos de sua produção. A maioria dos produtores entrevistados é do sexo masculino, de 26 a 50 anos, possuem propriedades de até 20 hectares, renda mensal de até quatro salários mínimos e contam apenas com a mão de obra da família, por isso são considerados agricultores familiares e já cultivam ou têm interesse em cultivar morango em substrato.

Palavras-chave: Fragaria ananassa, caracterização socioeconômica, agricultura familiar.

Received on January 14, 2020; accepted on September 15, 2020

Otrawberry crop (Fragaria $\mathrm{x}$ Oananassa) has an important socioeconomic impact on family farming (Gomes et al., 2013). Strawberry is grown in small areas (Madail, 2008) and, in Rio Grande do Sul, strawberry crop represents the main income source for many family farmers, being a consolidated activity in several regions of this state (Lazarotto \& Fioravanço, 2011). Three regions stand out as the main growing producers: Campos de Cima da Serra, "Serra" (the mountains) and the south part of the state, in which, the municipalities of Pelotas, Turuçu, São Lourenço and Canguçu represent the leading producers (IBGE, 2010).
In many municipalities of the south part of Rio Grande do Sul, the cultivation of strawberry in protected environment, using substrate as an alternative of conventional cultivation in soil, has been increasing significantly in the last years. This cultivation system was first described by Bortolozzo et al. (2007) as being a system presenting several advantages, when compared to a conventional system, considering labor optimization, the best ergonomic comfort and reduced pesticide use. Another benefit, associated with the use of neutral-day cultivars, is the shorter off-season period (Otto et al., 2009).

Cultivation in substrate has been advancing over the years. Nevertheless, there is no knowledge about the producers' point of view and the level of adoption of this new technology and more detailed characteristics of the areas where strawberries are grown in the south part of the state.

Obtaining information about the profile of the socioeconomic status and the cultivation system used by strawberry growers, in the south part of Rio Grande do Sul State, is essential in order to identify the specific needs of the customers, helping, this way, adapt and facilitate technical assistance to a new production reality. According to Chaer et al. (2011), a questionnaire is an 
efficient tool to get information, since its cost is reasonable and it is an easy way to survey and standardize data, as it also guarantees anonymity and uniformity.

Given the above, this study aimed to know the strawberry producers' profile, in these regions, and characterize the production systems adopted.

\section{MATERIAL AND METHODS}

The study was carried out in October and November 2017, through a structured questionnaire, applied to 30 strawberry producers, face to face and no interviewing intervention. Data were collected in the municipalities of the south region of Rio Grande do Sul: Pelotas, Turuçu, Piratini and Santa Vitória do Palmar.

The questionnaire was related to socioeconomic aspects of the producers, such as age, family income, educational level, area, exploration mode and nature of the job on the property. We also asked about the production system adopted, mainly in the area where strawberries were grown.

To characterize the producers in relation to their age, the following age groups were used: up to 25 years old; 26 to 50 years old; over 50 years old. We made up questions about the level of education considering: no schooling; complete and incomplete elementary school; complete and incomplete high school; technical course; complete undergraduate education; graduation. Regarding monthly family income, we took into account the number of minimum wages received, considering the regional minimum wage updated during the interview period. We also asked about the importance of strawberry crop in the income, cultivation system, cultivars, and marketing used. Regarding the substrate cultivation system, producers were asked how much they knew about it, if they were keen to use this system for growing strawberries and what difficulties they would have to face.

The results obtained were submitted to non-parametric statistical analysis, using $\mathrm{SAS} \circledast$ software, and graphical synthesis was performed using SigmaPlot 10.0.
When a questionnaire is applied, it is important to be able to assess whether the instrument used in the research can infer or measure what is actually proposed, giving relevance to the study (Matthiensen, 2011). To obtain internal consistency, that is, to valid the extent to which the items in this questionnaire are representative, only one concept was measured. The authors calculated Cronbach's alpha coefficient (Cronbach, 1951) using the formula below, where $\mathrm{n}=$ number of interviewed producers, $\sigma_{\mathrm{k}}^{2}=$ variance of $\mathrm{n}$ scores of people to $\mathrm{i}$-th item $(\mathrm{i}=1, \ldots, \mathrm{k})$ and $\sigma_{\mathrm{x}}^{2}=$ variance of total scores $(j=1,2, \ldots, n)$ of each interviewed producer:

$$
\alpha=\frac{n}{n-1}\left(\frac{\sum_{k-1}^{n} \sigma_{k}^{2}}{\sigma^{2} x}\right)
$$

Cronbach's alpha coefficient is a statistical tool which quantifies, from 0 to 1 , the reliability of a questionnaire. The minimum acceptable value, for considering a questionnaire reliable, is 0.7 .

\section{RESULTS AND DISCUSSION}

The questionnaire applied was considered reliable, showing a Cronbach's alpha coefficient of 0.7 , reducing any chances of doubts arising related to the obtained results (Richardson, 2015). According to the results, firstly, we noticed farmers' receptivity to answering the questions. Even not being an item to be evaluated in the survey, it indicates that farmers are interested in collaborating with academic research which will contribute to agricultural production.

Regarding the interviewed individuals, most of them are men, between 26 and 50 years old, incomplete elementary school. Although at relatively low levels, the survey data show some female growers in this group, also young people who are up to 25 years old. The answers also show that a part of the interviewees has a technical degree, undergraduation and graduation courses. However, regardless of education level, $72.4 \%$ consider agriculture to be their main activity (Figure 1).

In Figure 2, we observe that $79.4 \%$ of rural properties have up to 20 hectares, characterizing the predominance of small properties in the region. The vast majority of the interviewees is landowner, lives in the region and relies only on family labor. The monthly income of these families is around two to four minimum wages ( $\mathrm{R} \$ 2007.32$ to $\mathrm{R} \$ 4014.64)$, and not all the income comes from strawberry production, as some have other agricultural activities and/or receive retirement benefits. The other agricultural activities mentioned were production of other vegetables, grains, tobacco, fruit and livestock. Thus, the data showed that the majority of the interviewed producers can be characterized as family and that strawberry crop has a very important role for these families.

In relation to strawberry production system (Figure 3), 100\% of the interviewees are aware or have heard of soilless or substrate cultivation system: $43.3 \%$ is already working only with the system, $30 \%$ is producing strawberry in the soil and $26.7 \%$ is working using both cultivation systems. Most strawberry producers, who grow strawberries in substrate, use the open cultivation system (leachate free drainage system). Only $30 \%$ of the total producers use the closed system, that is, collect and reuse the solution nutrient leached by the system. Not only in Rio Grande do Sul, but throughout Brazil, most of the substrate growing systems for strawberry crop are open (Radin et al., 2011, Cecatto et al., 2013); 30\% adopt the closed system, this percentage seems to be low, though. However, this percentage is high when comparing with other strawberry producing regions. From the commercial point of view, the south region of the state was a pioneer in adopting the closed systems for the crop. No studies reported if any commercial strawberry farmers have adopted closed substrate growing systems in other producing regions of the state and in Brazil (Antunes et al., 2016). However, due to environmental problems, caused by open systems, such as contamination of soil and surface waters, authors like Gimenez et al. (2008) state that farmers are changing the systems they use, from open to closed cultivation systems. 
About the cultivation system, most of the farmers produce the plants using the conventional farming and the strawberry organic substrate production is still brand new. When the producers were questioned about substrate growing, they claimed they heard about it and showed interest in getting to know more about this growing system. In Rio Grande do Sul, some reports about experiences with substrates for

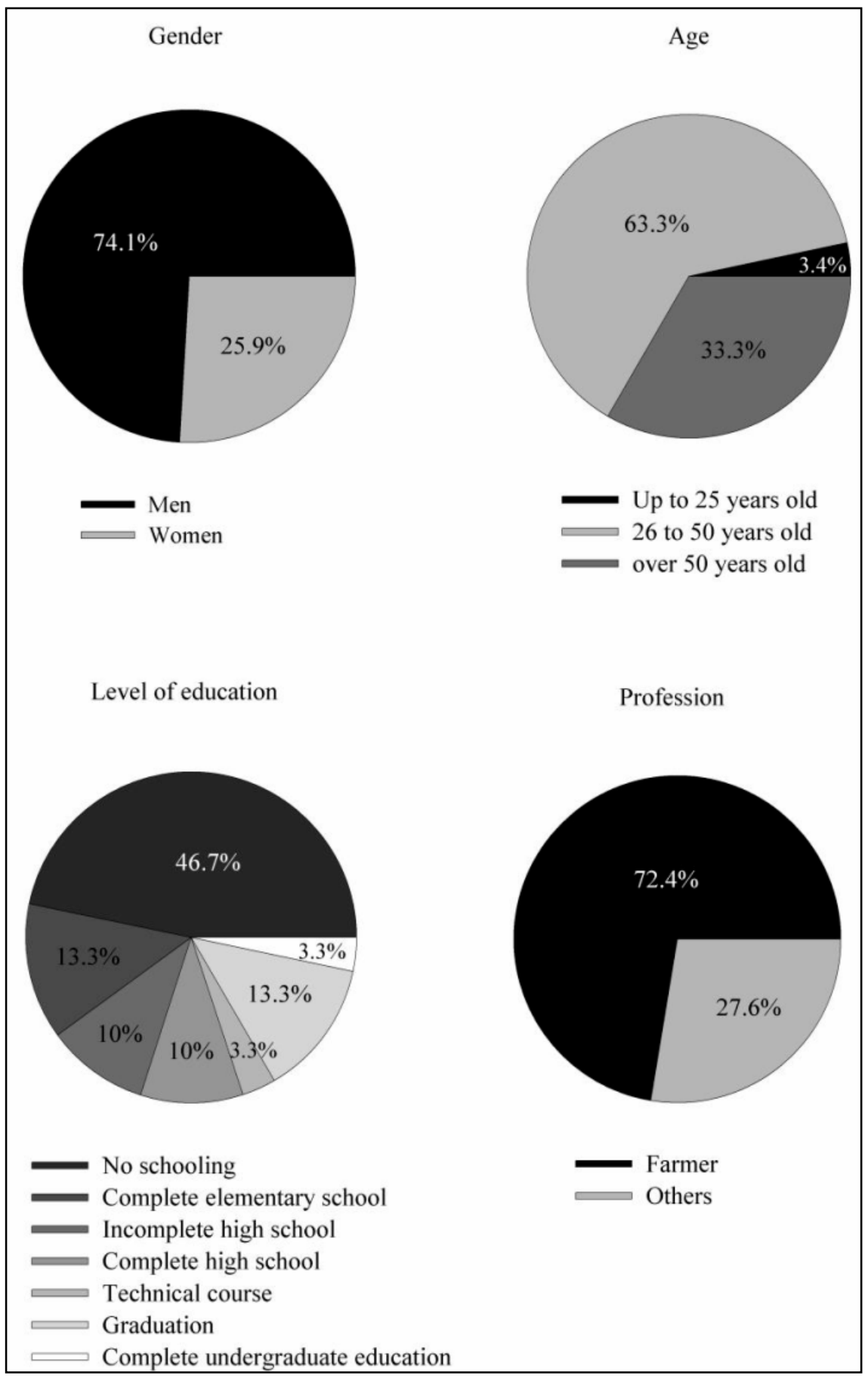

Figure 1. Sex, age, schooling and profession of strawberry producers from the south region of Rio Grande do Sul. Pelotas, UFPel, 2017.

strawberry production can be found, but they are still few and further studies are necessary (Santi \& Couto, 2012). According to Galina et al. (2013), under this system, the plants are grown inside "bags/pillows" (slabs), on benches in a protected environment, where a mixture of organic compounds is added. Plants are fertigated with boiled poultry manure in combination with biofertilizers. Organic production uses traditional

\section{som} Camarosa and Camino Real were the main produced cultivars.

The substrate cultivation was carried out, mostly in slabs, and some (30\%) of the production in plastic troughs (Figure 3 ). In this region (which is corroborated by the similar figure), farmers use an association of cultivation systems, slabs with open system and troughs, and closed system. In substrate cultivation, $55 \%$ of the interviewees grown over four thousand plants and $45 \%$ up to four thousand plants, being San Andreas and Albion the main grown cultivars.

The strawberry producers in Rio Grande do Sul, those who produce in soil, in most part, use short-day cultivars (DC), and the production is distributed along four to five months, showing production peaks in October/November, considering crop concentration a disadvantage in the use of these cultivars (Santos et al., 2003). The producers who use the substrate system, generally, use neutral day cultivars (DN), which shorten the off season period, having a strawberry production in summer months up to autumn, getting better prices in these periods (Otto et al., 2009).

National production of strawberry seedlings does not meet the demand of the main producer regions, considering quantity and quality; so $90 \%$ of the production areas in Brazil import seedlings (Gonçalves \& Antunes, 2016). This fact was confirmed analyzing the data obtained in the questionnaire. When asked about the origin of their seedlings, only $4 \%$ of the farmers answered that they obtain seedlings in Brazil. Most of the seedlings used are imported from the Patagonia region (Chile and Argentina). 


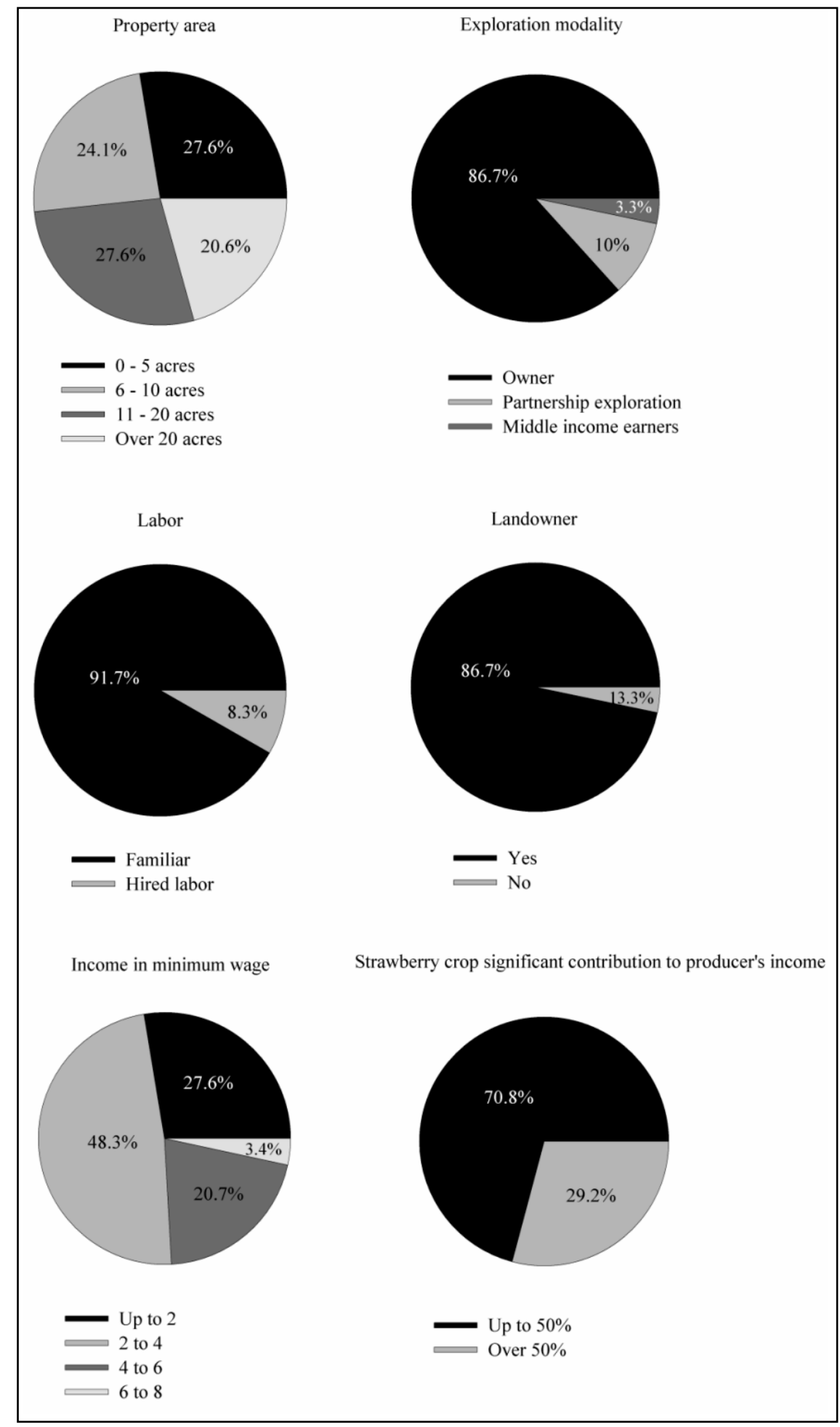

Figure 2. Property area, land exploration modality, labor, residence, income considering minimum wages and contribution of strawberry crop for the strawberry producers' income in the south region of Rio Grande do Sul. Pelotas, UFPel, 2017.

The use of imported seedlings has some advantages: guarantees that the material will be free of diseases, because, before entering Brazil, the seedlings undergo a phytosanitary inspection, and, generally, a higher production than the national
2006, 2009).

When asked about the greatest difficulties faced in cultivation, the most cited were scarcity of financial resources, adequate irrigation system and phytosanitary management problems. Thus, studies searching to identify the obstacles and difficulties faced by farmers are of great relevance, so that technical assistance can be guaranteed and academic research focused on real problems can be carried out. It is known that successive crops, combined with inadequate management practices, are causes of serious environmental problems to soil and groundwater, due to indiscriminate pesticide use in order to control pests and diseases, and also from the excessive nutrient use in irrigation water (Gimenez et al., 2008).

Another difficulty reported by producers refers to the market. Some reported difficulties delivering their products due to the low price intermediaries pay. That's why $82.8 \%$ sells directly to consumers and $17.2 \%$ sells to intermediaries. However, in Brazil, most organic product consumers (72\%) still buy in supermarkets, many have already been shopping for some products in small retailers: $42 \%$ go to specialized stores and $35 \%$ to producer markets (Kluth et al., 2010). In relation the way the product is presented, $44.8 \%$ sells it in bulk, $24.1 \%$ in packaging and $31 \%$ in both. According to the producers' reports regarding the prices paid, currently, the most common differentiation for fruit is related to the type of production system: conventional or organic. For organic products, in general, prices are much higher, $200 \mathrm{~g}$ of organic strawberries production cost is around $\mathrm{R} \$ 3.90$ and the average selling price set is $\mathrm{R} \$ 4.37$, profit margins in the range of $20 \%$ (Zachow et al., 2018).

The study concluded that strawberry crop is very important for the interviewees' families. According to obtained data, most producers are family members and they rarely hire workers. The biggest problems faced by producers were also identified, such as, pests and insects on the property, financial resources for investment, irrigation system, phytossanitary management and difficult access to the sales location. In 


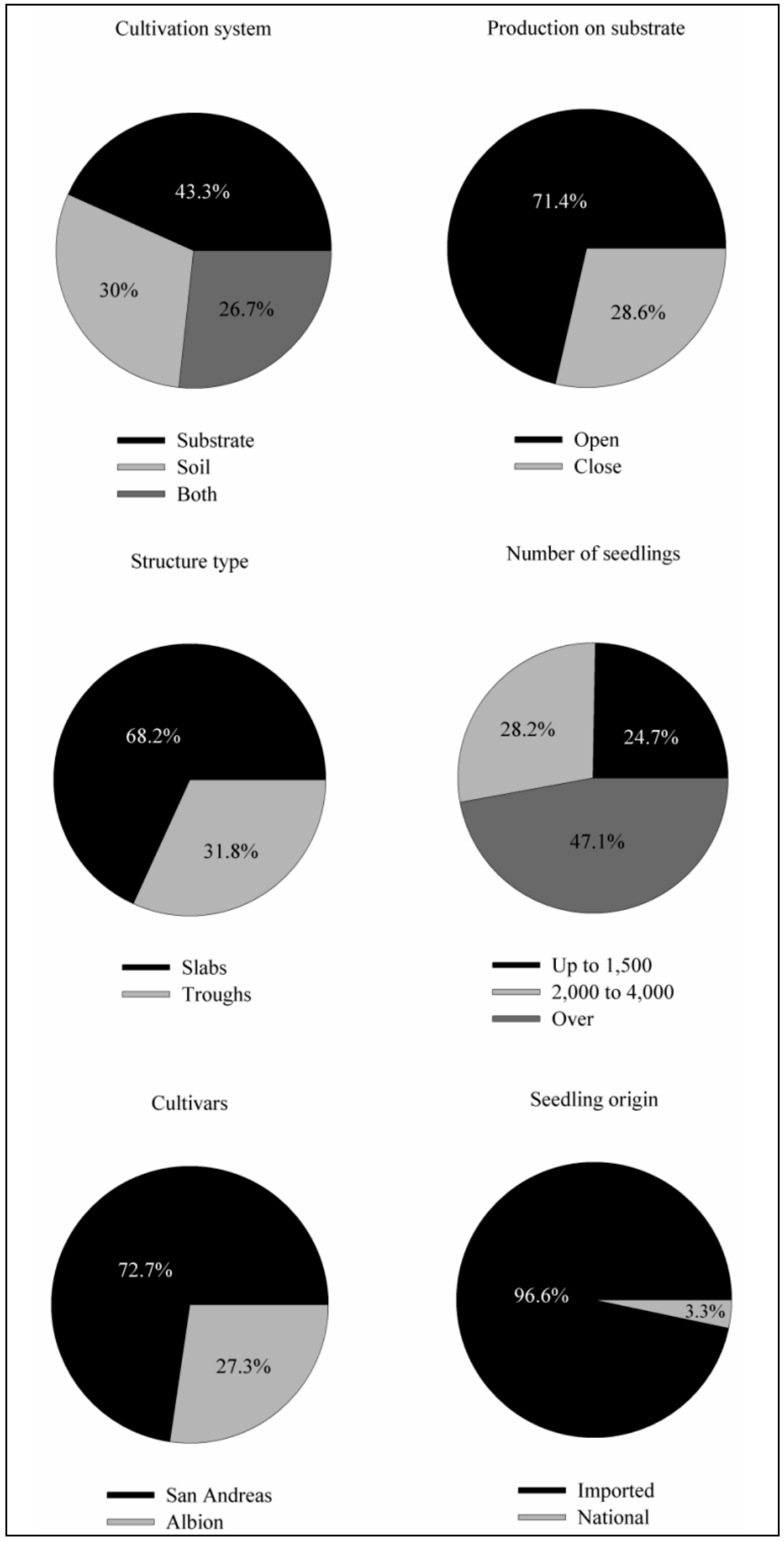

Figure 3. Cultivation systems (soil and substrate), origin of the seedlings and structures, quantity of seedlings and cultivars adopted in strawberry production in substrate in the south region of Rio Grande do Sul. Pelotas, UFPel, 2017. addition, the authors concluded that most of interviewees considered difficulties concerning marketing, bureaucracy and price as limiting causes for their production expansion. Therefore, this study achieved its goals: getting to know the strawberry producers' profile, taking into account the characteristics of their production and needs.

\section{ACKNOWLEDGEMENTS}

The authors thank the producers who took part in this study, answering the questionnaire. To Universidade Federal de Pelotas, Programa de Pósgraduação em Sistemas de Produção Agrícola Familiar (Graduate Program in Family Agricultural Production Systems) to carry out this study and to Coordination of Improvement of Higher Education Personnel (CAPES) for the students' scholarships. Roberta MN Peil thanks CNPq and PQ CNPq for financial support.

\section{REFERENCES}

ANTUNES, LEC; JÚNIOR, CR; SCHWENGBER, JE. 2016. Morangueiro. Brasília: Embrapa, 589p. Available: https://ainfo.cnptia.embrapa. br/digital/bitstream/item/179724/1/LuisEduardo-Morangueiro-miolo.pdf. Accessed April 28, 2020.

BORTOLOZZO, AR; SANHUEZA, RMV; BOTTON, M; MELO, GWB; KOVALESKI, A; BERNARDI ,J; HOFMANN A; VARGAS, L; CALEGARIO, FF; FERLA, NJ; PINENT, SMJ. 2007. Produção de morangos no sistema semi-hidropônico. Bento Gonçalves: Embrapa Uva e Vinho, Circular Técnica, 23 p.

CECATTO, AP; CALVETE, EO; NIENOW, AA; COSTA, RC; MENDONÇA, HFC; PAZZINATO, AC. 2013. Culture systems in the production and quality of strawberry cultivars. Acta Scientiarum Agronomy 35: 471-478.

CHAER, G; DINIZ, RRP; RIBEIRO, EA. 2011. A técnica do questionário na pesquisa educacional. Evidência 7: 251-266.

CRONBACH, LJ. 1951. Coefficient alpha and the internal structure of test. Psychometrika 16: 297-334.

GALINA, J; ILHA, L; PAGNONCELLI, J. 2013. Cultivo orgânico do morangueiro em substrato. Cadernos de Agroecologia 8: 14879-14884.

GIMENEZ, G; ANDRIOLO, JL; GODOI, R. 2008. Cultivo sem solo do morangueiro. Ciência Rural 38: 273-279.

GOMES, KBP; OLIVIER, GHH; CARVALHO, JP; CAVALCANTE, DFS; VILLA-REAL, 
ME. 2013. Diagnóstico da cadeia produtiva do morango dos agricultores familiares do Distrito Federal. Revista Eixo 2: 9-14.

GONÇALVES, MA; ANTUNES, LEC. 2016. Mudas sadias: o início do sucesso no cultivo de morango. Campo \& Negócio - Hortifruti 128: 48-51.

IBGE - Uso da terra no estado do Rio Grande do Sul: Brasil, Rio de Janeiro, 2010. Available at https://biblioteca.ibge.gov.br/visualizacao/ livros/liv95891.pdf Accessed April 28, 2020.

KLUTH, B; BOCCHI JUNIOR, U; CENSKOWSKY, U. 2010. Pesquisa sobre o comportamento e a percepção do consumidor de alimentos orgânicos no Brasil. München: Organic Services/Jundiaí: Vitalfood, 38p.

LAZAROTTO, JJ; FIORAVANÇO, JC. 2011. Estudo de caso da eficiência econômica e viabilidade financeira da produção de morango em sistema semi-hidropônico. Bento Gonçalves: Embrapa Uva e Vinho. Circular
Técnica. 16p.

MADAIL, JCMA. 2008. Economia do morango. In: SIMPÓSIO NACIONAL DO MORANGO, 4.; ENCONTRO SOBRE PEQUENAS FRUTAS E FRUTAS NATIVAS DO MERCOSUL, 3. Palestras \& resumos... Pelotas: CPACT.

MATTHIENSEN, A. 2011. Uso do coeficiente alfa de Cronbach em avaliações por questionários. Boa Vista: Embrapa Roraima, Documentos. $31 \mathrm{p}$.

OLIVEIRA, RP; SCIVITTARO, WB. 2006. Desempenho produtivo de mudas nacionais e importadas de morangueiro. Revista Brasileira de Fruticultura 28: 520-522.

OLIVEIRA, RP; SCIVITTARO, WB. 2009. Produção de frutos de morango em função de diferentes períodos de vernalização de mudas. Horticultura Brasileira 27: 91-95.

OTTO, RF; MORAKAMI, RK; REGHIN, MY; CAIRES, EF. 2009. Cultivares de morango de dia neutros: produção em função de doses de nitrogênio durante o verão. Horticultura Brasileira 27: 217-221.

RADIN, B; LISBOA, B; WITTER, S; BARNI, V; REISSER JUNIOR, C; MATZENAUER, R; FERMINO, MH. 2011. Desempenho de quatro cultivares de morangueiro em duas regiões ecoclimáticas do Rio Grande do Sul. Horticultura Brasileira 29: 287-291.

RICHARDSON, RJ. 2015. Pesquisa social: métodos e técnicas. São Paulo: 329p.

SANTI, FC; COUTO, WR. 2012. Morango em cultivo orgânico. Revista Científica Eletrônica de Ciências Aplicadas da FAIT 2: 43-52.

SANTOS, AM; MEDEIROS ARM; HERTER FG. 2003. Morango Produção. Brasília: Embrapa Informação Técnológica. p. 18-21.

ZACHOW, M; DOTTO, MLG; FIEDLER, L; TAGLIAPIETRA, OM; BERTOLINI, GRF. 2018. Formação do preço de venda do morango orgânico a partir dos custos de produção. Revista de Ciências Empresariais da UNIPAR 19: 243-256. 